ఠ

\title{
Nonalcoholic steatohepatitis-related hepatocellular carcinoma: is there a role for the androgen receptor pathway?
}

This article was published in the following Dove Press journal:

OncoTargets and Therapy

3 March 2017

Number of times this article has been viewed

\author{
Mahmoud A Ali \\ Sahin Lacin' \\ Reham Abdel-Wahab ${ }^{1,2}$ \\ Mark Uemura' \\ Manal Hassan' \\ Asif Rashid ${ }^{3}$ \\ Dan G Duda ${ }^{4}$ \\ Ahmed O Kaseb'
}

'Department of Gastrointestinal Medical Oncology, The University of Texas MD Anderson Cancer Center, Houston, TX, USA; ${ }^{2}$ Department of Clinical Oncology, Assiut University, Assiut, Egypt; ${ }^{3}$ Department of Pathology, The University of Texas MD Anderson Cancer Center, Houston, TX, ${ }^{4}$ Department of Radiation Oncology, Massachusetts General Hospital and Harvard Medical School, Boston, MA, USA
Correspondence: Ahmed O Kaseb Department of Gastrointestinal Medical Oncology, Unit 426, The University of Texas MD Anderson Cancer Center, I5I 5 Holcombe Blvd., Houston,

TX 77030, USA

$\mathrm{Tel}+\mathrm{I} 7137922828$

$\mathrm{Fax}+|7| 3745$ II63

Email akaseb@mdanderson.org
Abstract: The epidemic of insulin resistance, obesity, and metabolic syndrome has led to the emergence of nonalcoholic steatohepatitis (NASH) as the most common cause of liver disease in the US. Patients with NASH are at an increased risk for hepatic disease-related morbidity and death, and chronic inflammation in NASH patients can lead to hepatocellular carcinoma (HCC). The prevalence of HCC is higher in males than in females, and genetic studies have identified androgen and androgen receptors (ARs) as partially responsible for the gender disparity in the development of liver disease and HCC. Although many factors are known to play important roles in the progression of inflammation in NASH patients, the role of androgen and AR in the progression of NASH to HCC has been understudied. This review summarizes the evidence for a potential role of androgen and the AR pathway in the development of NASH-related HCC and in the treatment of HCC. It has been proposed that AR plays a role in the progression of HCC: inhibitory roles in early stages of hepatocarcinogenesis and tumor-promoting roles in advanced stages. AR can be activated by several pathways, even in the absence of androgen. While AR has been explored as a potential therapeutic target in HCC, several clinical trials have failed to demonstrate a clinical benefit of antiandrogen drugs in HCC. This review discusses the potential reason for these observations and discuss the potential future trials design in this important setting.

Keywords: hepatocellular carcinoma, nonalcoholic steatohepatitis, androgen receptor, flutamide, sorafenib

\section{Introduction}

Hepatocellular carcinoma (HCC) is an aggressive neoplasm with a poor prognosis, resulting in a 5-year relative survival rate of only $17.2 \%$ and an estimated 24,550 deaths in the US in 2015. ${ }^{1}$ Over the last three decades, the incidence of HCC in the US has increased from 1.4 per 100,000 to 8.2 per 100,000 per year. ${ }^{2}$ The incidence of HCC is higher in developing countries, particularly those in the Asian Pacific regions, owing to the high prevalence of chronic hepatitis $\mathrm{B}$ and $\mathrm{C}$ viral infections. However, the incidence in developed countries has also been increasing owing to the emergence of nonalcoholic steatohepatitis (NASH) as an important risk factor. . $^{3,4}$ In fact, recently, a large retrospective study demonstrated that the proportion of nonvirus-related HCC increased from $10 \%$ in 1991 to $24.1 \%$ in 2010 , with most cases related to nonalcoholic fatty liver disease (NAFLD) and diabetes. ${ }^{5-7}$ In a Japanese study, the 5-year HCC development rates in cirrhosis patients were $11.3 \%$ in NAFLD cirrhosis, $12.5 \%$ in alcoholic cirrhosis, and $30.5 \%$ in hepatitis $\mathrm{C}$ virus cirrhosis, showing similar rates of HCC development in both alcoholic and NAFLD-related cirrhosis. ${ }^{8}$ 
Although metabolic syndrome had the lowest relative risk among other factors for HCC $(1.5 \%-2.5 \%)$, its high prevalence in the general population $(30 \%-40 \%)$ led to the highest population-attributable fraction. ${ }^{9}$

Regardless of the underlying etiology, the incidence of $\mathrm{HCC}$ is higher in males, with male-to-female ratios varying between $3: 1$ and 4:1 depending on geographic location. ${ }^{10,11}$ Moreover, males have poorer survival despite there being many treatment options. ${ }^{12-14}$ The increased incidence and disease aggressiveness in males suggest that androgen and androgen receptors (ARs) might promote HCC development and progression and/or that estrogen and estrogen receptors might suppress HCC development. ${ }^{15}$ This review summarizes the evidence for the potential role of androgen and ARs in NAFLD/NASH-related HCC.

\section{NAFLD pathogenesis}

NAFLD is the most common cause of liver dysfunction, with a prevalence of $20 \%-30 \%$ in the general population and up to $57 \%-74 \%$ among obese patients. ${ }^{16}$ NAFLD was usually considered to be one of the components of the metabolic syndrome and to be strongly linked to central obesity, insulin resistance, dyslipidemia, and hypertension (Table 1). ${ }^{17-22}$ Recent studies support the association of NAFLD with type 2 diabetes mellitus or metabolic syndrome, suggesting that NAFLD actually precedes the development of both conditions and is considered as a risk factor for development of type 2 diabetes mellitus. ${ }^{23}$ NAFLD includes disorders ranging from isolated liver steatosis (in which triglycerides accumulate in the hepatocytes), characterized by macrovesicular fatty change with or without nonspecific inflammation in the absence of cellular injury (ballooning), to NASH (characterized by the presence of additional cellular ballooning) and, subsequently, to cirrhosis and even HCC. ${ }^{24-26}$ Fibrosis is the most important determinant of the outcome.

The molecular pathogenesis of liver steatosis and its progression to cirrhosis and eventually HCC is not clearly understood. Previously, a two-hit theory had been proposed to explain the molecular changes through which fatty liver leads to lipid peroxidation, cytokine production, and Fas ligand induction. ${ }^{27}$ However, more recently, a multiple-hit theory which better explains NAFLD development and progression to HCC has gained ground. The first hit is caused by insulin resistance and leads to fat accumulation in the hepatocytes, induced by both lipolysis and hyperinsulinemia. This is followed by multiple hits with many factors playing different roles, including genetic predisposition, obesity, oxidative stress and mitochondrial dysfunction, inflammation, adipokines, small intestinal microbacteria, and others. Hyperinsulinemia could also lead to increased levels of insulin growth factor-1, which causes stimulation of insulin growth factor receptors and promotion of proliferative and antiapoptotic effects, and vascular endothelial growth factormediated promotion of angiogenesis. ${ }^{28}$

Thus, in this setting, the liver is more susceptible to oxidative stress and inflammatory cytokines such as interleukin-6 (IL-6) and tumor necrosis factor- $\alpha$ (TNF- $\alpha$ ), which promote progression to NASH and fibrosis. IL-6 activates signal

Table I Five parameters of the metabolic syndrome according to the WHO and AACE

\begin{tabular}{|c|c|c|c|c|c|c|}
\hline Parameter & WHO (1998) & IDF (2005) & EGIR (I999) & NCEP-ATP III & ATP III (200I) & AHA/NHLBI (2005) \\
\hline $\begin{array}{l}\text { Required for } \\
\text { diagnosis }\end{array}$ & Insulin resistance & $\begin{array}{l}\text { Ethnicity-based } \\
\text { increased waist } \\
\text { circumference }\end{array}$ & Insulin resistance & - & $\begin{array}{l}\text { Any three out of } \\
\text { five }\end{array}$ & Any three out of five \\
\hline $\begin{array}{l}+ \text { Number of } \\
\text { abnormalities }\end{array}$ & $\geq 2$ & $\geq 2$ & $\geq 2$ & $\geq 3$ & - & - \\
\hline Glucose & DM & $\geq 100 \mathrm{mg} / \mathrm{dL}$ & DM & $\geq 100 \mathrm{mg} / \mathrm{dL}$ & $\geq 110 \mathrm{mg} / \mathrm{dL}$ & $\geq 100 \mathrm{mg} / \mathrm{dL}$ \\
\hline $\begin{array}{l}\text { HDL } \\
\text { cholesterol }\end{array}$ & $\begin{array}{l}\text { Males }<35 \mathrm{mg} / \mathrm{dL} \\
\text { females }<39 \mathrm{mg} / \mathrm{dL}\end{array}$ & $\begin{array}{l}\text { Males }<40 \mathrm{mg} / \mathrm{dL} \\
\text { females }<50 \mathrm{mg} / \mathrm{dL}\end{array}$ & $\begin{array}{l}\text { Males and females } \\
>39 \mathrm{mg} / \mathrm{dL}\end{array}$ & $\begin{array}{l}\text { Males }<40 \mathrm{mg} / \mathrm{dL} \\
\text { females }<50 \mathrm{mg} / \mathrm{dL}\end{array}$ & $\begin{array}{l}\text { Males }<40 \mathrm{mg} / \mathrm{dL} \\
\text { females }<50 \mathrm{mg} / \mathrm{dL}\end{array}$ & $\begin{array}{l}\text { Males }<40 \mathrm{mg} / \mathrm{dL} \\
\text { females }<50 \mathrm{mg} / \mathrm{dL}\end{array}$ \\
\hline Triglycerides & $\geq 150 \mathrm{mg} / \mathrm{dL}$ & $\geq 150 \mathrm{mg} / \mathrm{dL}$ & $\geq 150 \mathrm{mg} / \mathrm{dL}$ & $\geq 150 \mathrm{mg} / \mathrm{dL}$ & $\geq 150 \mathrm{mg} / \mathrm{L}$ & $\geq 150 \mathrm{mg} / \mathrm{L}$ \\
\hline Obesity & $\begin{array}{l}\text { Waist/hip }>0.9 \\
\text { (males) or }>0.85 \\
\text { (females); BMI } \geq 30 \\
\mathrm{~kg} / \mathrm{m}^{2}\end{array}$ & $\begin{array}{l}\text { WC: } \\
\text { males } \geq 102 \mathrm{~cm}, \\
\text { females } \geq 88 \mathrm{~cm}\end{array}$ & $\begin{array}{l}\text { WC: } \text { males } \geq 94 \\
\mathrm{~cm} \text {, females } \geq 80 \\
\mathrm{~cm}\end{array}$ & $W C \geq 94 \mathrm{~cm}$ & $\begin{array}{l}\text { WC: } \text { males } \geq 102 \\
\mathrm{~cm}, \text { females } \geq 88 \mathrm{~cm}\end{array}$ & $\begin{array}{l}\text { WC: males } \geq 102 \mathrm{~cm} \text {, } \\
\text { females } \geq 88 \mathrm{~cm}\end{array}$ \\
\hline Hypertension & $\begin{array}{l}\geq 140 / 90 \mathrm{mmHg} \\
\text { or use of } \\
\text { antihypertensive } \\
\text { drugs }\end{array}$ & $\begin{array}{l}\geq 130 / 85 \mathrm{mmHg} \\
\text { or use of } \\
\text { antihypertensive } \\
\text { drugs }\end{array}$ & $\begin{array}{l}\geq 140 / 90 \mathrm{mmHg} \\
\text { or use of } \\
\text { antihypertensive } \\
\text { drugs }\end{array}$ & $\begin{array}{l}\geq 130 / 85 \mathrm{mmHg} \\
\text { or use of } \\
\text { antihypertensive } \\
\text { drugs }\end{array}$ & $\begin{array}{l}\geq 130 / 85 \mathrm{mmHg} \\
\text { or use of } \\
\text { antihypertensive } \\
\text { drugs }\end{array}$ & $\begin{array}{l}>130 / 85 \mathrm{mmHg} \\
\text { or use of } \\
\text { antihypertensive } \\
\text { drugs }\end{array}$ \\
\hline
\end{tabular}

Abbreviations: AACE, American Association of Clinical Endocrinologists; BMI, body mass index; DM, diabetes mellitus; HDL, high density lipoprotein; WC, waist circumference; WHO, World Health Organization; IDF, International Diabetes Federation; EGIR, European Group for the Study of Insulin Resistance; NCEP-ATPIII, National Cholesterol Education Program Adult Treatment Panel III; ATP III, Adult Treatment Panel III. 
transducer and activator of transcription 3 , which induces cell proliferation and antiapoptotic mechanisms. TNF- $\alpha$ activates pro-oncogenic pathways, including c-Jun N-terminal kinase, nuclear factor kappa-light-chain-enhancer of activated B cells, mammalian target of rapamycin, and the extracellular signal-regulated kinases. ${ }^{29-32}$ interestingly, several studies indicated that both dietary and genetic obesity could promote liver inflammation and tumorigenesis by enhancing IL- 6 and TNF- $\alpha$ expression. ${ }^{33-36}$

Finally, the high circulating levels of leptin in NAFLD have been recently shown to exert proinflammatory and profibrogenic effects. ${ }^{37,38}$ In addition, there is evidence that lipid peroxides and free radicals are elevated in metabolic syndrome; these may cause oxidative injury, endoplasmic reticulum stress, mitochondrial dysfunction, and apoptosis. ${ }^{15}$

\section{Role of gender differences in NAFLD}

Several studies have shown that gender differences play a role in various liver disorders. Earlier beliefs that NAFLD/ NASH was a female-predominant condition have been dispelled; recent studies have shown higher prevalence in males. ${ }^{39-46}$ Interestingly, in a preclinical study, a high-fat, high-cholesterol diet induced NASH and hepatic ballooning in ovariectomized mice, which showed that estrogen deficiency promoted NASH progression, while estrogen treatment reversed it. ${ }^{47}$ Furthermore, many studies have shown that NAFLD patients have significantly lower levels of sex hormone binding globulin, a glycoprotein that binds to sex hormones (both estrogen and androgen). ${ }^{48,49}$ Increased prevalence of NAFLD has also been reported in patients with polycystic ovary syndrome (PCOS) ${ }^{50,51}$ Diethylnitrosamine administration caused greater increase in serum IL-6 in male than in female mice. Also, ablation of IL- 6 abolished the gender differences in hepatocarcinogenesis in mice. ${ }^{52,53}$

However, the roles of androgen in the development of NAFLD remain unclear, as the results of experimental and clinical studies have been inconsistent. ${ }^{54,55}$ For example, Jones et al found a significantly higher degree of hepatic steatosis in high-androgen-expressed PCOS patients as compared to low-androgen-expressed PCOS patients or controls. ${ }^{56}$ Another study observed that androgenic steroid usage by bodybuilders could be a possible risk factor for NAFLD.${ }^{57}$ In contrast, Haider et al showed that normalizing serum testosterone levels in obese hypogonadal males could improve their weight loss and metabolic state and suppress the development of NASH. ${ }^{58}$

The role of ARs in the pathogenesis of NAFLD is also unclear. An experimental study showed that whole-body
AR-knockout mice fed a high-fat diet developed liver steatosis and insulin resistance, possibly through either 1) suppression of fatty acid synthesis by decreased sterol regulatory element-binding protein 1 (SREBP1) expression or 2) increased insulin sensitivity by suppression of phosphoenolpyruvate carboxykinase and protein tyrosine phosphatase 1B. ${ }^{59}$ Notably, other studies showed that activation of AR in orchidectomized mice led to obesity and altered lipid metabolism, and progression of NASH to HCC. ${ }^{60}$ This may have been mediated either through downregulation of liver X receptor (which complements SREBP2 activation and increases cellular cholesterol levels) or through upregulation of AR messenger RNA levels and increased activity of CYP27A1 (an enzyme that plays a significant role in cholesterol homeostasis and vitamin D3 metabolism through activation of the c-Jun N-terminal kinase pathway). ${ }^{61,62}$

\section{Prevention of $\mathrm{NASH} /$ metabolic syndrome-related $\mathrm{HCC}$ using existing drugs}

Statins (3-hydroxy-3-methyl-glutaryl-CoA reductase inhibitors) are commonly prescribed for prevention of cardiovascular disease and act by decreasing the biosynthesis of cholesterol. Statins may play a role in the prevention of cancer development by inducing apoptosis and inhibiting cellular proliferation, angiogenesis, inflammation, and immunomodulation. ${ }^{63}$ In multiple observational studies,${ }^{64-67}$ the use of statins has been associated with a decreased risk of HCC in patients with viral hepatitis and those with diabetes, and statins may also decrease the risk of HCC recurrence after surgical treatment. ${ }^{68}$ However, a randomized controlled trial did not demonstrate a significant difference in HCC incidence between the statin and placebo groups. ${ }^{69}$

In diabetic patients, the use of both metformin and thiazolidinediones (peroxisome proliferator-activated receptor gamma agonists) was associated with a decreased cancer risk, whereas sulfonylurea was correlated with an increased overall risk of cancer..$^{70}$ Also, the use of combined statin and metformin in diabetic patients showed no benefit to reduce the risk of $\mathrm{HCC}$ in Asian population..$^{71}$ Metformin has been shown to inhibit hepatocellular proliferation and leads to arrest of the cell cycle at the G0/G1 phase by downregulation of cyclin $\mathrm{D} 1,{ }^{72}$ while thiazolidinediones were reported to decrease the risk of HCC by accumulation of $\mathrm{p} 27$, inhibition of ubiquitin-proteasome, MEK-ERK signaling, and induction of apoptosis. ${ }^{70,73,74}$ Also, drugs of proven antifibrogenic efficacy may potentially decrease the risk of developing $\mathrm{HCC} .{ }^{75}$ 


\section{Mechanistic pathway of androgen and ARs in hepatocarcinogenesis}

Both estrogen and androgen are steroid hormones that mediate their action by binding to nuclear receptors and acting as transcription factors to regulate the expression of multiple genes. Progression from hyperplasia to HCC is associated with suppression of estrogen receptors and elevated AR expression. ${ }^{76-80}$ In addition, several studies ${ }^{81}$ have shown that AR messenger RNA protein is expressed at higher levels in hepatic tumor tissue than in normal hepatic tissue. The $A R$ gene is located on the X chromosome with a single copy in males. The AR molecule is a ligand-activated transcriptional factor with three domains the N-terminal domain, the DNA-binding domain, and the ligand-binding domain. ${ }^{82}$ ARs can be activated directly by androgen, inducing cell cycle-relatd kinase (CCRK) transcription through promoter binding; CCRK then upregulates $\beta$-catenin/T-cell factor signaling, leading to promotion of hepatocarcinogenesis..$^{83}$ ARs can also be activated directly in the absence of androgen by many alternative pathways such as the mitogen-activated protein kinase, AKt, and signal transducer and activator of transcription pathways, which are also involved in hepatocarcinogenesis (Figure 1). ${ }^{84,85}$ In an experimental study, adding functional ARs to HCC cells promoted cell growth and increased cellular oxidative stress, DNA damage, and suppression of the p53-mediated sensing/repairing system and of cell apoptosis. ${ }^{86}$ Furthermore, several studies have shown that AR is expressed in both normal liver and malignant tissues, but at higher levels in HCC tumor tissue..$^{56,61,86}$

\section{Clinical evidence of androgen's role in promoting $\mathrm{HCC}$ recurrence and metastasis}

Several clinical studies have reported a strong correlation between AR expression and the rate of HCC recurrence (summarized in Table 2). ${ }^{87-89}$ However, there is controversy regarding the relationship between AR and tumor characteristics such as size, another factor that affects tumor recurrence..$^{57,70}$

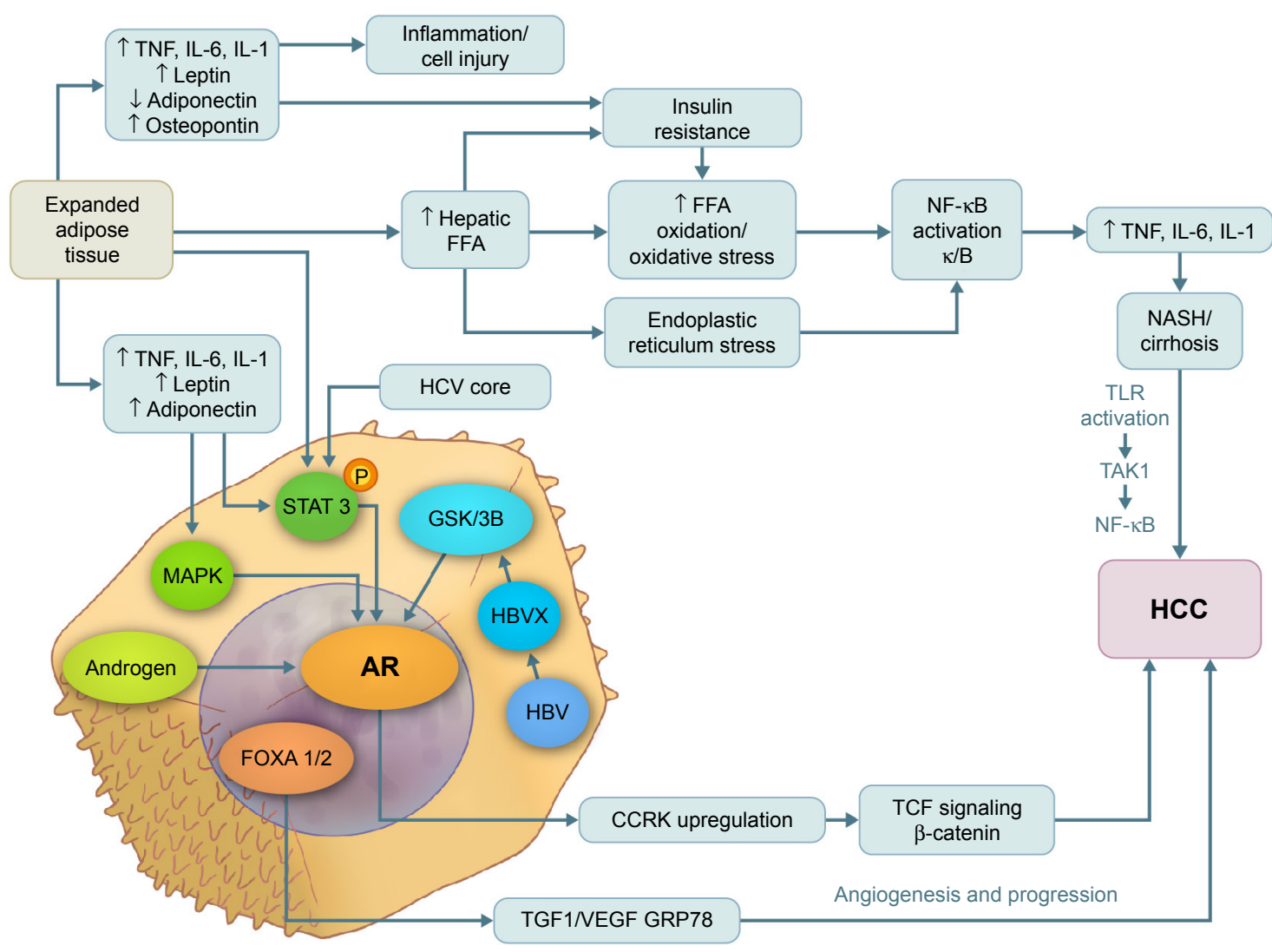

Figure I Pathways of androgen and AR in the pathogenesis of NASH, cirrhosis, and hepatocellular carcinoma.

Note: Visual Art: (C) 2015 The University of Texas MD Anderson Cancer Center.

Abbreviations: AR, androgen receptor; CCRK, cycle cycle-related kinase; HBV, hepatitis B virus; HCC, hepatocellular carcinoma; HCV, hepatitis C virus; IL, interleukin; MAPK, mitogen-activated protein kinase; NASH, nonalcoholic steatohepatitis; NF-KB, nuclear factor kappa-light-chain-enhancer of activated B cells; STAT 3, signal transducer and activator of transcription 3; TNF, tumor necrosis factor; VEGF, vascular endothelial growth factor; GSK3b, glycogen synthase kinase 3 beta; FFA, free fatty acid; HBVX, hepatitis B virus protein X; TGFI, tumor growth factor I. 
Table 2 Clinical studies that evaluated the role of androgen and its receptors in the recurrence of surgically treated HCC

\begin{tabular}{|c|c|c|c|c|c|c|c|c|}
\hline Author & Year & Country & $\begin{array}{l}\text { Sample } \\
\text { size }\end{array}$ & $\begin{array}{l}\text { HCC risk } \\
\text { factor }\end{array}$ & $\operatorname{Sex}(M / F)$ & AR expression & Recurrence rate & Survival rate \\
\hline \multirow[t]{4}{*}{ Nagasue et a ${ }^{87}$} & 1989 & Japan & 45 & Alcoholic I5 & $31 / 12$ & $31 \mathrm{AR}+(25 \mathrm{M} / 4 \mathrm{~F})$ & $A R+67.9 \%$ & $\begin{array}{l}\text { AR+ I year: } 84 \% \text {; } \\
5 \text { years: } 17.3 \%\end{array}$ \\
\hline & & & & $\mathrm{HBsAg} 24$ & & $14 \mathrm{AR}-(6 \mathrm{M} / 8 \mathrm{~F})$ & $A R-33.3 \%$ & $\begin{array}{l}\text { AR- I year: } 100 \% \\
5 \text { years: } 62.2 \%\end{array}$ \\
\hline & & & & AntiHbc 32 & & & & \\
\hline & & & & AntiHBs I5 & & & & \\
\hline \multirow[t]{2}{*}{ Boix et al ${ }^{88}$} & 1995 & Spain & 43 & Cirrhosis 40 & $30 / 13$ & $30 \mathrm{AR}+$ & AR+ I year: $34 \% ; 2$ years: $51 \%$ & Not reported \\
\hline & & & & Normal 3 & & $13 \mathrm{AR}-$ & AR- I year: $0 \% ; 2$ years: $20 \%$ & \\
\hline
\end{tabular}

Abbreviations: AntiHbc, Anti Hepatitis B core antibodies; antiHBs, antihepatitis B surface antibodies; AR, androgen receptor; F, female; HBsAg, hepatitis B surface antigen; HCC, hepatocellular carcinoma; M, male.

Moreover, the role of AR in promoting metastasis in $\mathrm{HCC}$ has been understudied. A few studies have reported a role for AR in metastatic HCC lesions, which may include the following: 1) AR activation by its ligand leads to increased expression of IDI (a metastasis-promoting gene), which causes HCC cell migration and invasion ${ }^{90}$ or 2) tighter and faster adhesion of the cancer cells to collagen IV and various extracellular membranes occurs through $\beta 1$ integrin expression induced by activated ARs. ${ }^{91}$ The latter effect of AR on cell adhesion was shown to be mediated by the $\beta 1$ integrin-phosphoinositide-3-kinase (PI3K)/Akt pathway. In contrast, another study found that AR expression was significantly reduced in advanced metastatic lesions compared with early primary HCC lesions, with the AR upregulated in tumors $<3 \mathrm{~cm} .{ }^{92}$

\section{Effect of antiandrogen treatment on HCC outcome}

Despite the mounting evidence suggesting the potential role of the AR pathway as a therapeutic target in HCC, data on the use of antiandrogens are limited to a few clinical trials and no definite activity has been reported using this strategy (Table 3) ${ }^{87,93-99}$ One reason for the failure of these clinical trials could be the fact that these studies included mostly advanced and metastatic HCC patients, and the role of AR in late-stage $\mathrm{HCC}$ - whether it promotes or suppresses invasion and metastasis - remains unclear. Also, AR expression might be more critical than androgen concentration in $\mathrm{HCC}^{92}$ and no correlative studies have tested the predictive value of expression of AR in the tissue of HCC patients. Finally, most trials were performed on viral hepatitis-induced HCC, which may not have the same histologic characteristics or pathogenesis as non-hepatitis-induced HCC. The biological heterogeneity of HCC makes the prognosis of tumor growth, survival of patients, and treatment outcomes difficult. ${ }^{100-102}$

\section{Current systemic therapy in HCC: potential role of $A R$}

Currently, single-agent sorafenib, a putative multitargeted kinase inhibitor, is the only systemic therapy approved by the US Food and Drug Administration to treat patients with advanced HCC. Sorafenib prolongs the overall survival by approximately 3 months in this population ${ }^{13}$ Phase II studies of other targeted drugs such as sunitinib, linifanib, erlotinib, ramucirumab, and everolimus demonstrated promising results in the management of late-stage HCC, but Phase III studies of these agents did not show overall survival benefit in unselected patient populations. ${ }^{103-105}$ Notably, subgroup analyses of the Sorafenib HCC Assessment Randomized Protocol (SHARP) trial suggested that survival outcomes varied with patient demographics, geographic location, and risk factors. Interestingly, recent Phase II studies of other agents, including two studies in the first-line treatment setting conducted by the group using the combination of bevacizumab and erlotinib, showed activity in HCC, $103,106-111$ which also suggested differential outcomes based on patients' demographics, geographic locations, and risk factors.

Another important factor that affects the outcome in HCC patient population is their tolerance to therapies, given the coexistence of $\mathrm{HCC}$ tumors and underlying liver disease in most of the cases. Although the adverse effects of targeted therapy are usually tolerable, serious complications can develop, especially with higher doses or in combination with another angiogenic agent or with chemotherapy. Fatigue, diarrhea, and hand/foot skin reaction are the most common dose-limiting side effects, with bleeding, arterial thromboembolism, and other fatal complications also possible..$^{13}$ Therefore, increasing the efficiency of sorafenib and other targeted therapies by combination with other drugs that increase their efficacy while maintaining a lower dose is essential. 


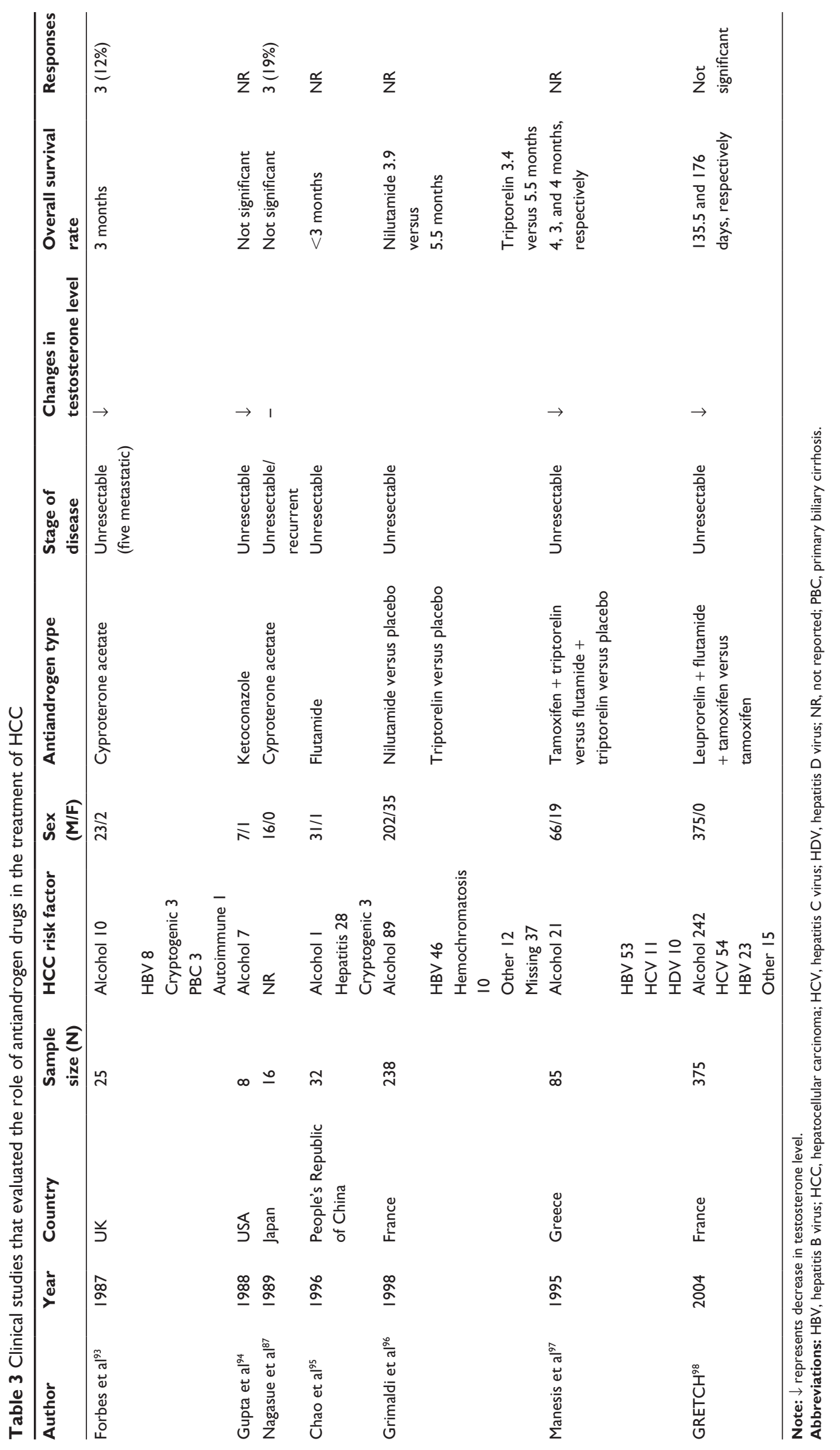


AR was found to suppress HCC metastasis by modulating $\mathrm{p} 38$. Also, the addition of functional AR in SKhep1 and HepG2 HCC cells was found to decrease p38, leading to enhanced effectiveness of sorafenib against HCC cells. ${ }^{92}$ In preclinical studies, sorafenib treatment had greater antimetastatic effects against AR-positive than AR-negative HCC (66.7\% vs $0 \%$, respectively; $P=0.0109)$. Another study showed that sorafenib with or without AR inhibitors induced significant apoptosis in HCC cells with knocked out AR when compared with unmanipulated HCC cells; the authors concluded that inhibition of AR in combination with sorafenib may be beneficial for the treatment of HCC..$^{90,111}$ These data suggest that AR may be a target of combination therapy, and that AR expression may be a potential biomarker of response to sorafenib in HCC.

\section{Conclusion}

Androgen and ARs may play a critical role in hepatocarcinogenesis and could mediate, in part, the mechanisms responsible for the gender disparity in $\mathrm{HCC}$ incidence. ARs can be activated both by androgen and, in the absence of androgen, by alternative pathways. Liver steatosis can progress into NASH, which can lead to cirrhosis and HCC. The high prevalence of NASH in the general population led to recent significant increase in incidence of NASH-related HCC cases. Gender disparity appears to play a significant role in the development of NASH, as NASH is more common in males than in females and also contributes to higher risk of HCC development. Nevertheless, the clinical trials conducted so far have failed to demonstrate a significant benefit of antiandrogen drugs in the treatment of HCC patients. This failure could be explained, at least partially, by 1) the marked heterogeneity of $\mathrm{HCC}$, with most trials performed on virus-induced HCC; 2) the dual, yet opposite effects of AR during early and late $\mathrm{HCC}$, with most trials performed on advanced HCC only; and 3) the direct stimulation of AR by pathways other than androgen. Therefore, it is critical to understand the molecular mechanisms associated with HCC in males with NASH to design successful targeted therapy studies focusing on AR pathway.

\section{Acknowledgments}

Editorial assistance was provided by Michael Worley and the Department of Scientific Publications at MD Anderson Cancer Center.

This work was supported by MD Anderson Cancer Center (to AOK).

\section{Disclosure}

The authors report no conflicts of interest in this work.

\section{References}

1. Ferlay J, Shin HR, Bray F, Forman D, Mathers C, Parkin DM. Estimates of worldwide burden of cancer in 2008: GLOBOCAN 2008. Int $J$ Cancer. 2010;127(12):2893-2917.

2. El-Serag HB, Lau M, Eschbach K, Davila J, Goodwin J. Epidemiology of hepatocellular carcinoma in hispanics in the United States. Arch Intern Med. 2007;167(18):1983-1989.

3. Welzel TM, Graubard BI, Zeuzem S, El-Serag HB, Davila JA, McGlynn KA. Metabolic syndrome increases the risk of primary liver cancer in the United States: a study in the SEER-Medicare database. Hepatology (Baltimore, Md). 2011;54(2):463-471.

4. Baffy G, Brunt EM, Caldwell SH. Hepatocellular carcinoma in non-alcoholic fatty liver disease: an emerging menace. J Hepatol. 2012; 56(6):1384-1391.

5. Tateishi R, Okanoue T, Fujiwara N, et al. Clinical characteristics, treatment, and prognosis of non-B, non-C hepatocellular carcinoma: a large retrospective multicenter cohort study. J Gastroenterol. 2015;50(3):350-360.

6. White DL, Kanwal F, El-Serag HB. Association between nonalcoholic fatty liver disease and risk for hepatocellular cancer, based on systematic review. Clin Gastroenterol Hepatol. 2012;10(12):1342-1359.e2.

7. Facciorusso A. The influence of diabetes in the pathogenesis and the clinical course of hepatocellular carcinoma: recent findings and new perspectives. Curr Diabetes Rev. 2013;9(5):382-386.

8. Tokushige K, Hashimoto E, Kodama K. Hepatocarcinogenesis in nonalcoholic fatty liver disease in Japan. J Gastroenterol Hepatol. 2013; 28(Suppl 4):88-92.

9. Welzel TM, Graubard BI, Quraishi S, et al. Population-attributable fractions of risk factors for hepatocellular carcinoma in the United States. Am J Gastroenterol. 2013;108(8):1314-1321.

10. Hefaiedh R, Ennaifer R, Romdhane H, et al. Gender difference in patients with hepatocellular carcinoma. Tunis Med. 2013;91(8-9):505-508.

11. El-Serag HB. Hepatocellular carcinoma. N Engl J Med. 2011;365(12): 1118-1127.

12. Yamashita YI, Yoshida Y, Kurihara T, et al. Surgical results for recurrent hepatocellular carcinoma after curative hepatectomy: repeat hepatectomy vs. salvage living donor liver transplantation. Liver Transpl. 2015;21(7): 961-968.

13. Llovet JM, Ricci S, Mazzaferro V, et al. Sorafenib in advanced hepatocellular carcinoma. N Engl J Med. 2008;359(4):378-390.

14. Lee DH, Lee JM, Lee JY, Kim SH, Han JK, Choi BI. Radiofrequency ablation for intrahepatic recurrent hepatocellular carcinoma: long-term results and prognostic factors in 168 patients with cirrhosis. Cardiovascu Intervent Radiol. 2014;37(3):705-715.

15. Cazanave SC, Mott JL, Elmi NA, et al. JNK1-dependent PUMA expression contributes to hepatocyte lipoapoptosis. J Biol Chem. 2009; 284(39):26591-26602.

16. Angulo P. Nonalcoholic fatty liver disease. N Engl J Med. 2002; 346(16):1221-1231.

17. Alberti KG, Zimmet PZ. Definition, diagnosis and classification of diabetes mellitus and its complications. Part 1: diagnosis and classification of diabetes mellitus provisional report of a WHO consultation. Diabet Med. 1998;15(7):539-553.

18. Grundy SM, Cleeman JI, Daniels SR, et al; American Heart Association; National Heart, Lung, and Blood Institute. Diagnosis and management of the metabolic syndrome: an American Heart Association/National Heart, Lung, and Blood Institute Scientific Statement. Circulation. 2005;112(17): 2735-2752.

19. Alberti KG, Zimmet P, Shaw J. Metabolic syndrome - a new worldwide definition. A consensus statement from the international diabetes federation. Diabet Med. 2006;23(5):469-480.

20. Isomaa B, Almgren P, Tuomi T, et al. Cardiovascular morbidity and mortality associated with the metabolic syndrome. Diabetes Care. 2001; 24(4):683-689.

21. Expert Panel on Detection, Evaluation, and Treatment of High Blood Cholesterol in Adults. Executive summary of the third report of The National Cholesterol Education Program (NCEP) expert panel on detection, evaluation, and treatment of high blood cholesterol in adults (adult treatment panel III). JAMA. 2001;285(19):2486-2497. 
22. Essah PA, Nestler JE. The metabolic syndrome in polycystic ovary syndrome. J Endocrinol Invest. 2006;29(3):270-280.

23. Lonardo A, Ballestri S, Marchesini G, Angulo P, Loria P. Nonalcoholic fatty liver disease: a precursor of the metabolic syndrome. Dig Liver Dis. 2015;47(3):181-190.

24. Byrne CD, Olufadi R, Bruce KD, Cagampang FR, Ahmed MH. Metabolic disturbances in non-alcoholic fatty liver disease. Clin Sci (Lond). 2009;116(7):539-564.

25. Rinella ME. Nonalcoholic fatty liver disease: a systematic review. JAMA. 2015;313(22):2263-2273.

26. Kubes P, Mehal WZ. Sterile inflammation in the liver. Gastroenterology. 2012;143(5):1158-1172.

27. Wiegand J, Mossner J, Tillmann HL. [Non-alcoholic fatty liver disease and non-alcoholic steatohepatitis]. Der Internist. 2007;48(2):154-163. German.

28. Tomimaru Y, Koga H, Yano H, de la Monte S, Wands JR, Kim M. Upregulation of T-cell factor-4 isoform-responsive target genes in hepatocellular carcinoma. Liver Int. 2013;33(7):1100-1112.

29. Bian Z, Ma X. Liver fibrogenesis in non-alcoholic steatohepatitis. Front Physiol. 2012;3:248.

30. Wu J, Zhang J, Shen B, et al. Long noncoding RNA lncTCF7, induced by IL-6/STAT3 transactivation, promotes hepatocellular carcinoma aggressiveness through epithelial-mesenchymal transition. J Exp Clin Cancer Res. 2015;34:116.

31. Jung IH, Choi JH, Chung YY, Lim GL, Park YN, Park SW. Predominant activation of JAK/STAT3 pathway by Interleukin-6 is implicated in hepatocarcinogenesis. Neoplasia. 2015;17(7):586-597.

32. Wan S, Zhao E, Kryczek I, et al. Tumor-associated macrophages produce interleukin 6 and signal via STAT3 to promote expansion of human hepatocellular carcinoma stem cells. Gastroenterology. 2014;147(6): 1393-1404

33. Bugianesi E, Pagotto U, Manini R, et al. Plasma adiponectin in nonalcoholic fatty liver is related to hepatic insulin resistance and hepatic fat content, not to liver disease severity. J Clin Endocrinol Metab. 2005; 90(6):3498-3504.

34. Musso G, Gambino R, Durazzo M, et al. Adipokines in NASH: postprandial lipid metabolism as a link between adiponectin and liver disease. Hepatology. 2005;42(5):1175-1183.

35. Ding X, Saxena NK, Lin S, Xu A, Srinivasan S, Anania FA. The roles of leptin and adiponectin: a novel paradigm in adipocytokine regulation of liver fibrosis and stellate cell biology. Am J Pathol. 2005;166(6):1655-1669.

36. Park EJ, Lee JH, Yu GY, et al. Dietary and genetic obesity promote liver inflammation and tumorigenesis by enhancing IL-6 and TNF expression. Cell. 2010;140(2):197-208.

37. Awazawa M, Ueki K, Inabe K, et al. Adiponectin suppresses hepatic SREBP1c expression in an AdipoR1/LKB1/AMPK dependent pathway. Biochem Biophys Res Commun. 2009;382(1):51-56.

38. Ikejima K, Okumura K, Kon K, Takei Y, Sato N. Role of adipocytokines in hepatic fibrogenesis. J Gastroenterol Hepatol. 2007;22(Suppl 1): S87-S92.

39. Weston SR, Leyden W, Murphy R, et al. Racial and ethnic distribution of nonalcoholic fatty liver in persons with newly diagnosed chronic liver disease. Hepatology. 2005;41(2):372-379.

40. Baig S. Gender disparity in infections of hepatitis B virus. J Coll Physicians Surg Pak. 2009;19(9):598-600.

41. Browning JD, Szczepaniak LS, Dobbins R, et al. Prevalence of hepatic steatosis in an urban population in the United States: impact of ethnicity. Hepatology. 2004;40(6):1387-1395.

42. Bacon BR, Farahvash MJ, Janney CG, Neuschwander-Tetri BA. Nonalcoholic steatohepatitis: an expanded clinical entity. Gastroenterology. 1994;107(4):1103-1109.

43. Marchesini G, Bugianesi E, Forlani G, et al. Nonalcoholic fatty liver, steatohepatitis, and the metabolic syndrome. Hepatology. 2003;37(4): 917-923.

44. Angelico F, Del Ben M, Conti R, et al. Non-alcoholic fatty liver syndrome: a hepatic consequence of common metabolic diseases. J Gastroenterol Hepatol. 2003;18(5):588-594.
45. Kral JG, Schaffner F, Pierson RN Jr, Wang J. Body fat topography as an independent predictor of fatty liver. Metabolism. 1993;42(5):548-551.

46. Omagari K, Kadokawa Y, Masuda J, et al. Fatty liver in non-alcoholic non-overweight Japanese adults: incidence and clinical characteristics. J Gastroenterol Hepatol. 2002;17(10):1098-1105.

47. Kamada Y, Kiso S, Yoshida Y, et al. Estrogen deficiency worsens steatohepatitis in mice fed high-fat and high-cholesterol diet. Am J Physiol Gastrointest Liver Physiol. 2011;301(6):G1031-G1043.

48. Polyzos SA, Kountouras J, Tsatsoulis A, et al. Sex steroids and sex hormone-binding globulin in postmenopausal women with nonalcoholic fatty liver disease. Hormones. 2013;12(3):405-416.

49. Shin JY, Kim SK, Lee MY, et al. Serum sex hormone-binding globulin levels are independently associated with nonalcoholic fatty liver disease in people with type 2 diabetes. Diabetes Res Clin Pract. 2011;94(1): $156-162$.

50. Vassilatou E. Nonalcoholic fatty liver disease and polycystic ovary syndrome. World J Gastroenterol. 2014;20(26):8351-8363.

51. Ciotta L, Pagano I, Stracquadanio M, Formuso C. [Polycystic ovarian syndrome incidence in young women with non-alcoholic fatty liver disease]. Minerva Ginecol. 2011;63(5):429-437. Italian.

52. Naugler WE, Sakurai T, Kim S, et al. Gender disparity in liver cancer due to sex differences in MyD88-dependent IL-6 production. Science. 2007;317(5834):121-124

53. Prieto J. Inflammation, HCC and sex: IL-6 in the centre of the triangle. J Hepatol. 2008;48(2):380-381.

54. Zhang H, Liu Y, Wang L, et al. Differential effects of estrogen/androgen on the prevention of nonalcoholic fatty liver disease in the male rat. J Lipid Res. 2013;54(2):345-357.

55. Chow JD, Jones ME, Prelle K, Simpson ER, Boon WC. A selective estrogen receptor alpha agonist ameliorates hepatic steatosis in the male aromatase knockout mouse. J Endocrinol. 2011;210(3): 323-334.

56. Jones H, Sprung VS, Pugh CJ, et al. Polycystic ovary syndrome with hyperandrogenism is characterized by an increased risk of hepatic steatosis compared to nonhyperandrogenic PCOS phenotypes and healthy controls, independent of obesity and insulin resistance. J Clin Endocrinol Metab. 2012;97(10):3709-3716.

57. Schwingel PA, Cotrim HP, Salles BR, et al. Anabolic-androgenic steroids: a possible new risk factor of toxicant-associated fatty liver disease. Liver Int. 2011;31(3):348-353.

58. Haider A, Saad F, Doros G, Gooren L. Hypogonadal obese men with and without diabetes mellitus type 2 lose weight and show improvement in cardiovascular risk factors when treated with testosterone: an observational study. Obes Res Clin Pract. 2014;8(4): e339-e349.

59. Lin HY, Yu IC, Wang RS, et al. Increased hepatic steatosis and insulin resistance in mice lacking hepatic androgen receptor. Hepatology (Baltimore, Md). 2008;47(6):1924-1935.

60. Moverare-Skrtic S, Venken K, Andersson N, et al. Dihydrotestosterone treatment results in obesity and altered lipid metabolism in orchidectomized mice. Obesity (Silver Spring, Md). 2006;14(4):662-672.

61. Norlin M, Pettersson H, Tang W, Wikvall K. Androgen receptor-mediated regulation of the anti-atherogenic enzyme CYP27A1 involves the JNK/c-jun pathway. Arch Biochem Biophys. 2011;506(2): 236-641.

62. Krycer JR, Brown AJ. Cross-talk between the androgen receptor and the liver X receptor: implications for cholesterol homeostasis. J Biol Chem. 2011;286(23):20637-20647.

63. Lonardo A, Loria P. Potential for statins in the chemoprevention and management of hepatocellular carcinoma. J Gastroenterol Hepatol. 2012;27(11):1654-1664.

64. Lai SW, Liao KF, Lai HC, Muo CH, Sung FC, Chen PC. Statin use and risk of hepatocellular carcinoma. Eur J Epidemiol. 2013;28(6): 485-492.

65. Tsan YT, Lee CH, Wang JD, Chen PC. Statins and the risk of hepatocellular carcinoma in patients with hepatitis B virus infection. J Clin Oncol. 2012;30(6):623-630. 
66. El-Serag HB, Johnson ML, Hachem C, Morgana RO. Statins are associated with a reduced risk of hepatocellular carcinoma in a large cohort of patients with diabetes. Gastroenterology. 2009;136(5):1601-1608.

67. Singh S, Singh PP, Singh AG, Murad MH, Sanchez W. Statins are associated with a reduced risk of hepatocellular cancer: a systematic review and meta-analysis. Gastroenterology. 2013;144(2):323-332.

68. Wu CY, Chen YJ, Ho HJ, Hsu YC, Kuo KN, Wu MS. Association between nucleoside analogues and risk of hepatitis $\mathrm{B}$ virus-related hepatocellular carcinoma recurrence following liver resection. JAMA. 2012;308(18):1906-1914.

69. Emberson JR, Kearney PM, Blackwell L, et al; Cholesterol Treatment Trialists' (CTT) Collaboration. Lack of effect of lowering LDL cholesterol on cancer: meta-analysis of individual data from 175,000 people in 27 randomised trials of statin therapy. PLoS One. 2012;7(1):e29849.

70. Chang CH, Lin JW, Wu LC, Lai MS, Chuang LM. Oral insulin secretagogues, insulin, and cancer risk in type 2 diabetes mellitus. $J$ Clin Endocrinol Metab. 2012;97(7):E1170-E1175.

71. Chen HH, Lin MC, Muo CH, Yeh SY, Sung FC, Kao CH. Combination therapy of mtetformin and statin may decrease hepatocellular carcinoma among diabetic patients in Asia. Medicine. 2015;94(24):e1013.

72. Chen HP, Shieh JJ, Chang CC, et al. Metformin decreases hepatocellular carcinoma risk in a dose-dependent manner: population-based and in vitro studies. Gut. 2013;62(4):606-615.

73. Okumura T. Mechanisms by which thiazolidinediones induce anticancer effects in cancers in digestive organs. J Gastroenterol. 2010; 45(11):1097-1102.

74. Ruiter R, Visser LE, van Herk-Sukel MP, et al. Lower risk of cancer in patients on metformin in comparison with those on sulfonylurea derivatives: results from a large population-based follow-up study Diabetes Care. 2012;35(1):119-124.

75. Singh S, Khera R, Murad MH, Loomba R. Reply. Hepatology (Baltimore, Md). 2016;64(2):694.

76. Eagon PK, Elm MS, Epley MJ, Shinozuka H, Rao KN. Sex steroid metabolism and receptor status in hepatic hyperplasia and cancer in rats. Gastroenterology. 1996;110(4):1199-1207.

77. Ostrowski JL, Ingleton PM, Underwood JC, Parsons MA. Increased hepatic androgen receptor expression in female rats during diethylnitrosamine liver carcinogenesis. A possible correlation with liver tumor development. Gastroenterology. 1988;94(5 Pt 1):1193-1200.

78. Tejura S, Rodgers GR, Dunion MH, Parsons MA, Underwood JC, Ingleton PM. Sex-steroid receptors in the diethylnitrosamine model of hepatocarcinogenesis: modifications by gonadal ablation and steroid replacement therapy. J Mol Endocrinol. 1989;3(3):229-237.

79. Nakatani T, Roy G, Fujimoto N, Asahara T, Ito A. Sex hormone dependency of diethylnitrosamine-induced liver tumors in mice and chemoprevention by leuprorelin. Jpn J Cancer Res. 2001;92(3):249-256.

80. Feng H, Cheng AS, Tsang DP, et al. Cell cycle-related kinase is a direct androgen receptor-regulated gene that drives beta-catenin/T cell factordependent hepatocarcinogenesis. J Clin Invest. 2011;121(8):3159-3175.

81. Tian Y, Wong VW, Chan HL, Cheng AS. Epigenetic regulation of hepatocellular carcinoma in non-alcoholic fatty liver disease. Semin Cancer Biol. 2013;23(6 Pt B):471-482.

82. Gelmann EP. Molecular biology of the androgen receptor. J Clin Oncol. 2002;20(13):3001-3015.

83. Bolton EC, So AY, Chaivorapol C, Haqq CM, Li H, Yamamoto KR. Cell- and gene-specific regulation of primary target genes by the androgen receptor. Genes Dev. 2007;21(16):2005-2017.

84. Culig Z. Androgen receptor coactivators in regulation of growth and differentiation in prostate cancer. $J$ Cell Physiol. 2016;231(2):270-274.

85. Agoulnik IU, Weigel NL. Coactivator selective regulation of androgen receptor activity. Steroids. 2009;74(8):669-674.

86. Kalra M, Mayes J, Assefa S, Kaul AK, Kaul R. Role of sex steroid receptors in pathobiology of hepatocellular carcinoma. World J Gastroenterol. 2008;14(39):5945-5961.

87. Nagasue N, Kohno H, Chang YC, et al. Androgen and estrogen receptors in hepatocellular carcinoma and the surrounding liver in women. Cancer. 1989;63(1):112-116.
88. Boix L, Castells A, Bruix J, et al. Androgen receptors in hepatocellular carcinoma and surrounding liver: relationship with tumor size and recurrence rate after surgical resection. $J$ Hepatol. 1995;22(6):616-622.

89. Zhang X, He L, Lu Y, Liu M, Huang X. Androgen receptor in primary hepatocellular carcinoma and its clinical significance. Chin Med J. 1998;111(12):1083-1086.

90. Ao J, Meng J, Zhu L, et al. Activation of androgen receptor induces ID1 and promotes hepatocellular carcinoma cell migration and invasion. Mol Oncol. 2012;6(5):507-515.

91. Ma WL, Jeng LB, Lai HC, Liao PY, Chang C. Androgen receptor enhances cell adhesion and decreases cell migration via modulating beta1-integrin-AKT signaling in hepatocellular carcinoma cells. Cancer Lett. 2014;351(1):64-71.

92. Ma WL, Hsu CL, Yeh CC, et al. Hepatic androgen receptor suppresses hepatocellular carcinoma metastasis through modulation of cell migration and anoikis. Hepatology (Baltimore, Md). 2012;56(1):176-185.

93. Forbes A, Wilkinson ML, Iqbal MJ, Johnson PJ, Williams R. Response to cyproterone acetate treatment in primary hepatocellular carcinoma is related to fall in free 5 alpha-dihydrotestosterone. Eur J Cancer Clin Oncol. 1987;23(11):1659-1664.

94. Gupta S, Korula J. Failure of ketoconazole as anti-androgen therapy in nonresectable primary hepatocellular carcinoma. J Clin Gastroenterol. 1988;10(6):651-654

95. Chao Y, Chan WK, Huang YS, et al. Phase II study of flutamide in the treatment of hepatocellular carcinoma. Cancer. 1996;77(4):635-639.

96. Grimaldi C, Bleiberg H, Gay F, et al. Evaluation of antiandrogen therapy in unresectable hepatocellular carcinoma: results of a European Organization for Research and Treatment of Cancer multicentric double-blind trial. J Clin Oncol. 1998;16(2):411-417.

97. Manesis EK, Giannoulis G, Zoumboulis P, Vafiadou I, Hadziyannis SJ Treatment of hepatocellular carcinoma with combined suppression and inhibition of sex hormones: a randomized, controlled trial. Hepatology (Baltimore, Md). 1995;21(6):1535-1542.

98. Groupe d'Etude et de Traitement du Carcinome Hépatocellulaire. Randomized trial of leuprorelin and flutamide in male patients with hepatocellular carcinoma treated with tamoxifen. Hepatology (Baltimore, Md). 2004;40(6):1361-1369.

99. Di Maio M, De Maio E, Morabito A, et al. Hormonal treatment of human hepatocellular carcinoma. Ann N Y Acad Sci. 2006;1089:252-261.

100. Villa E, Critelli R, Lei B, et al. Neoangiogenesis-related genes are hallmarks of fast-growing hepatocellular carcinomas and worst survival. Results from a prospective study. Gut. 2016;65(5):861-869.

101. Weiskirchen R. Intratumor heterogeneity, variability and plasticity: questioning the current concepts in classification and treatment of hepatocellular carcinoma. Hepatobiliary Surg Nutr. 2016;5(2):183-187.

102. Li L, Wang H. Heterogeneity of liver cancer and personalized therapy. Cancer Lett. 2015;379(2):191-197.

103. Hsu CH, Kang YK, Yang TS, et al. Bevacizumab with erlotinib as first-line therapy in Asian patients with advanced hepatocellular carcinoma: a multicenter phase II study. Oncology. 2013;85(1):44-52.

104. Cainap C, Qin S, Huang WT, et al. Linifanib versus Sorafenib in patients with advanced hepatocellular carcinoma: results of a randomized phase III trial. J Clin Oncol. 2015;33(2):172-179.

105. Welker MW, Trojan J. Antiangiogenic treatment in hepatocellular carcinoma: the balance of efficacy and safety. Cancer Manag Res. 2013;5:337-347.

106. Govindarajan R, Siegel E, Makhoul I, Williamson S. Bevacizumab and erlotinib in previously untreated inoperable and metastatic hepatocellular carcinoma. Am J Clin Oncol. 2013;36(3):254-257.

107. Kaseb AO, Garrett-Mayer E, Morris JS, et al. Efficacy of bevacizumab plus erlotinib for advanced hepatocellular carcinoma and predictors of outcome: final results of a phase II trial. Oncology. 2012;82(2): 67-74.

108. Philip PA, Mahoney MR, Holen KD, et al. Phase 2 study of bevacizumab plus erlotinib in patients with advanced hepatocellular cancer. Cancer. 2012;118(9):2424-2430. 
109. Yau T, Wong H, Chan P, et al. Phase II study of bevacizumab and erlotinib in the treatment of advanced hepatocellular carcinoma patients with sorafenib-refractory disease. Invest New Drugs. 2012;30(6): 2384-2390.

110. Thomas MB, Morris JS, Chadha R, et al. Phase II trial of the combination of bevacizumab and erlotinib in patients who have advanced hepatocellular carcinoma. J Clin Oncol. 2009;27(6):843-850.
111. Jiang X, Kanda T, Nakamoto S, Miyamura T, Wu S, Yokosuka O. Involvement of androgen receptor and glucose-regulated protein $78 \mathrm{kDa}$ in human hepatocarcinogenesis. Exp Cell Res. 2014;323(2):326-336.

\section{Publish your work in this journal}

OncoTargets and Therapy is an international, peer-reviewed, open access journal focusing on the pathological basis of all cancers, potential targets for therapy and treatment protocols employed to improve the management of cancer patients. The journal also focuses on the impact of management programs and new therapeutic agents and protocols on

\section{Dovepress}

patient perspectives such as quality of life, adherence and satisfaction. The manuscript management system is completely online and includes a very quick and fair peer-review system, which is all easy to use. Visit http://www.dovepress.com/testimonials.php to read real quotes from published authors.

Submit your manuscript here: http://www.dovepress.com/oncotargets-and-therapy-journal 